\title{
COVID-19 Pandemic: Impact on Countries with Weak Health Systems
}

\author{
Muhammad Ahmed Abdullah', Farah Rashid ${ }^{2}$ \\ ${ }^{1}$ Assistant Professor, Department of Community Medicine, Islamabad Medical and Dental College \\ ${ }^{2}$ Professor and Head, Department of Community Medicine, Islamabad Medical and Dental College
}

The whole world has swiftly been overtaken by the COVID-19 pandemic within a short span of time. The total number of positive cases is 423,882 with 18,926 deaths globally ${ }^{1}$, on the day this manuscript was written. The disease rates blew up so rapidly with the help of technology. It spread from its epicenter through person to person contact, ${ }^{1}$ central heating and cooling systems in cruise ships, ${ }^{2}$ and spread to other countries though planes and ships. ${ }^{3}$ It is further spreading within countries mostly though public transport and gatherings. We are constantly being told that things will get worse before they get any better.

The situation in Europe and America looks grave, while China, the origin of the infection seems to have controlled the outbreak through a robustly authoritarian approach. Markets are plummeting and businesses around the world are going bankrupt. ${ }^{4}$ This is not the first time that humans have faced a pandemic of this proportion, but it is definitely the first time we are facing one, in a world controlled by technology.

The World Health Organization had warned during the early period of this outbreak that this virus would have a devastating effect on the countries with weaker health systems. ${ }^{5}$ This has been proven

Correspondence:

Muhammad Ahmed Abdullah

Email:drahmedabdullah83@gmail.com

Cite this Editorial: Abdullah MA, Rahid F. COVID-19

Pandemic: Impact on Countries with Weak Health Systems.

J Islamabad Med Dental Coll. 2020; 9(1):4-5.

Doi: $10.35787 /$ jimdc.v9i1.523 true in the case of Iran, ${ }^{6}$ however it also has far worse impacts on the countries with apparently the best healthcare systems of the world. Italy, Spain, United States of America and Germany are struggling immensely and are deeply affected by constantly escalating mortality and morbidity caused by the virus. ${ }^{7}$ A multitude of factors can be associated with such an outcome. Countries in South Asia and Africa have generally evaded the devastating effects of this virus. These countries share hotter and humid climates, the average hygiene level of the people exposes them to a large number of microorganisms on a daily basis. These countries also have shorter life expectancies and hence have a greater proportion of young people in their populations. Herd immunity might also be playing a role in this regard, with the virus floating freely in the masses. The recent discovery that SARS COV2 can be transmitted through saliva and fecal contact might also be loading the population with an immunizing dose unknowingly in a similar manner, as the Polio virus does. In our part of the world, we have been bracing for impact for a few weeks now, after watching the developed world crumble in the face of this unseen enemy; an impact that might neverappear.

What happened in Italy is unprecedented, supporting the general opinion that the virus apparently mutated into a much more aggressive strain when it landed in the country. Italy has the highest geriatric population in Europe with around $30 \%$ people above 60 years of age. Thus the virus had enough vulnerable population to infect giving 
rise to a large number of highly symptomatic cases, who were shedding large doses of the virus through coughing and sneezing. ${ }^{7}$ This might have exposed other age groups to large doses of the virus as well, leading to the healthcare system on the verge of collapse under this burden of death and disease. The same model is being replicated in the rest of Europe.

Lastly, we would like to state that unrealistic fears and phobias spread by the media and social media are not helping, as they are often not based on scientific evidence. Fear reduces human immunity and makes people susceptible to a wide range of diseases and adverse outcomes. In this time of myths and fallacies, the media needs to play an extremely important role of awareness and health promotion based on scientific evidence.

\section{References}

1. Paules $\mathrm{Cl}$, Marston $\mathrm{HD}$, Fauci AS. Coronavirus infections-more than just the common cold. JAMA. Published online January 23, 2020. Doi:10.1001/jama.2020.0757
2. Rocklöv J, Sjödin H, Wilder-Smith A. COVID-19 outbreak on the Diamond Princess cruise ship: estimating the epidemic potential and effectiveness of public health countermeasures. J Travel Med. 2020. Doi:10.1093/jtm/taaa030

3. Bogoch II, Watts A, Thomas-Bachli A, Huber C, Kraemer MU, Khan K. Potential for global spread of a novel coronavirus from China. J Travel Med. 2020; 27(2): taaa011. Doi: 10.1093/jtm/taaa011

4. Haushofer J, Metcalf CJ. Combining behavioral economics and infectious disease epidemiology to mitigate the COVID-19 outbreak. Working Paper, Princeton University. 2020.

5. Sohrabi C, Alsafi Z, O'Neill N, Khan M, Kerwan A, Al-Jabir A, losifidis C, Agha R. World Health Organization declares global emergency: A review of the 2019 novel coronavirus (COVID19). Int J Surg. 2020; 76: 71-76. Doi: 10.1016/j.ijsu.2020.02.034

6. Arab-Mazar Z, Sah R, Rabaan AA, Dhama K, Rodriguez-Morales AJ. Mapping the incidence of the COVID-19 hotspot in Iran-Implications for Travellers. Travel Med Infect Dis. 2020; 14: 101630. Doi: 10.1016/j.tmaid.2020.101630

7. Remuzzi A, Remuzzi G. COVID-19 and Italy: what next?. The Lancet. 2020. Doi: 10.1016/S01406736(20)30627-9. 